\title{
THE MANAGEMENT AND POTENTIAL RISK REDUCTIONIN THE PROCESSING OF RARE EARTHS ELEMENTS
}

doi: $\quad 10.2478 /$ czoto-2019-0010

Date of submission of the article to the Editor: 02/11/2018

Date of acceptance of the article by the Editor: 29/12/2018

Katarzyna Kapustka ${ }^{1}$ - orcid id: 0000-0003-4890-2807

Dorota Klimecka-Tatar ${ }^{2}$ - orcid id: 0000-0001-6212-6061

Gerhard Ziegmann ${ }^{1}$ - orcid id: 0000-0001-7914-8574

${ }^{1}$ University of Technology, Germany

${ }^{2}$ Czestochowa University of Technology, Poland, dorota.klimecka-tatar@wz.pcz.pl

\begin{abstract}
The rare earth elements (REE) are vital to innovation technologies and society and are important for the industry, especially for high-tech solutions. In the modern world, anumerous applications have been developed using rare earth elements (REE), implying human exposures and raising unclear questions as to REEassociated health effects. Protecting the environment and public health from disadvantageous actions of rare earth elements mining and processing as emerging pollutants is urgently desired to achieve sustainable development. All activities in mining processes like extraction, separation and after recycling of REE elements could create rick to human health and environment. In the paper the role of management in safety aspects during mining and processing of rare earth elements has been highlighted. In the paper, the potential dangerous and damaging effects on the environment and human health have been identified - the potential risk in the processing as well as the possibilities of preventing the occurrence of hazards have been analyzed.
\end{abstract}

Keywords: rare earth elements, risk management, ecological danger, human health

\section{INTRODUCTION}

The REEs are standard sub classified into "Heavy Rare Earths" (HREEs) and "Light Rare Earths" (LREEs). La, $\mathrm{Ce}, \mathrm{Pr}, \mathrm{Nd}, \mathrm{Pm}$ and $\mathrm{Sm}$ fall into subclass LREE (Balomenoset al., 2017). Y, Eu, Gd, Tb, Dy, Ho, Er, Tm, Yb and Lu fall into subclass HREE (Wells and Wells, 2001, as cited by U.S. EPA, 2009b, 2009c, 2009d). Yttrium is also included with REE group, because it has similar chemical and physical properties than the lanthanides. Scandium is found in most REE deposits and is sometimes classified as a rare earth element (Balomenos et al., 2017). Although yttrium is the lightest REE, it is usually included with the HREE group, because is has similar chemical and physical properties than HREEs (Wells and Wells, 2001, as cited by U.S. EPA, 2009b, 2009c, 2009d).Mostly REEs occur at trace levels in the upper continental crust total content ranging from $<1$ to $70 \mathrm{ppm}$ (Zepf, 2013). 
The geological conditions of metal mines are generally similar to the geological settings of REE deposits (Mubashir, 2018).Mining processes of REEs are also similar to the other hard rock mines and consequently the risk characterization of the metal mines is likely relevant to that of mining REEs (Balomenos et al., 2017).

\section{METHODOLOGY - CONCEPTUAL FRAMEWORK}

Protecting the environment and public health from disadvantageous actions of rare earth elements mining and processing as emerging pollutants is urgently desired to achieve sustainable development (Ali, 2014).A complete environmental risk assessment includes both; ecological and human health risk assessments and the preceding assessment of hazards and the related exposure concentration. the threat to human health may be caused by the lack or improper functioning of safety management systems (Niciejewska and Klimecka-Tatar, 2018; Pacana and Ulewicz, 2017). This article consists of both, ecological and health risk assessments that are collected and based on literature. The process phase are included: extraction, separation, mechanical production, recycling emissions of contaminants and the resulting concentrations in the surrounding media (Fig.1).

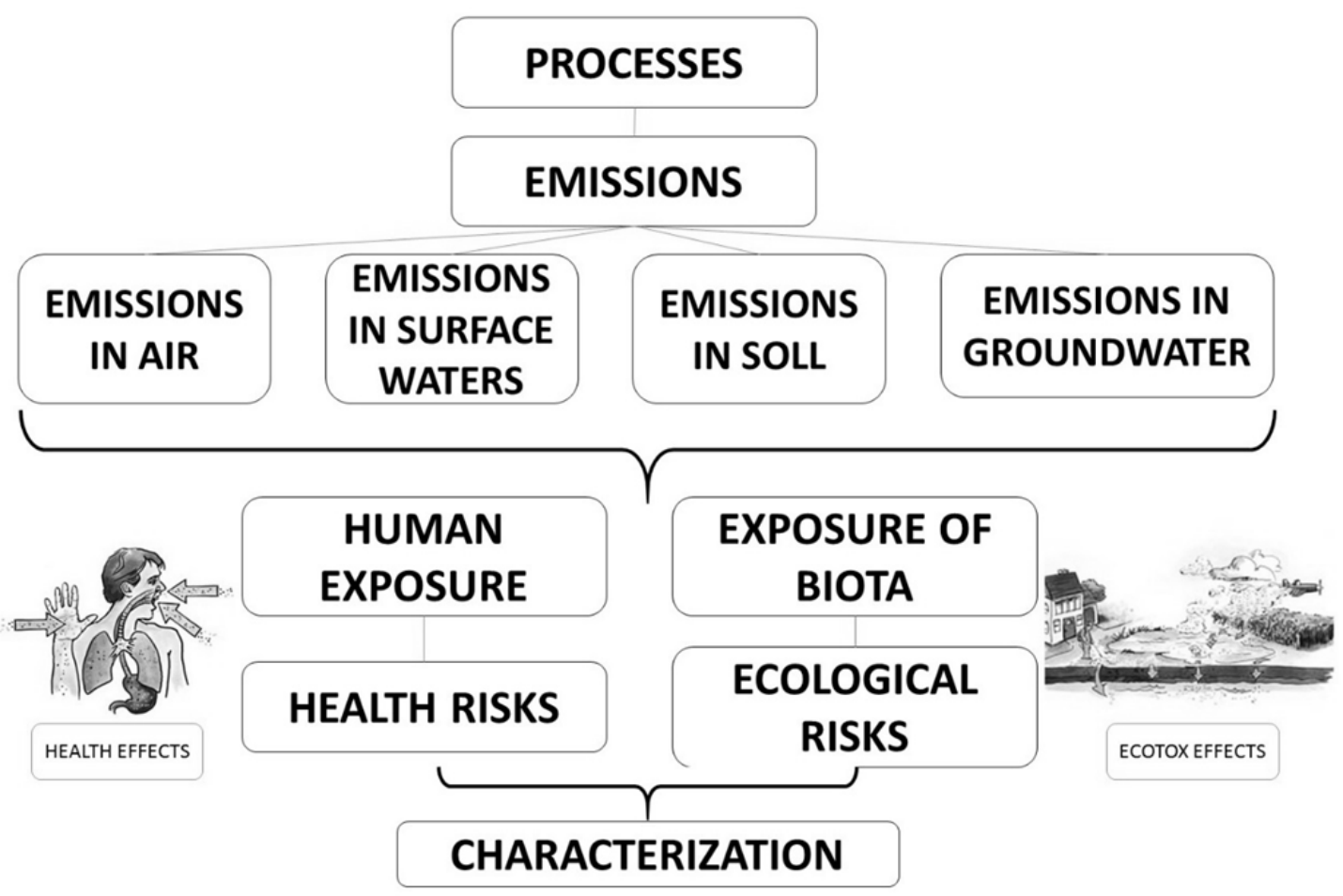

Fig. 1. General conceptual model for risk assessment

A conceptual model describes the sources of emissions, the mechanisms of the emission releases, the pathway and potential risks for human and ecological exposure to emissions in the environment (Pagano,2015). As analyzed by Weber, R. J., Reisman, D. J. 2012.that ten receptor types have been identified around the mine site during the life of time: construction works, outdoor worker, indoor worker, off-site tribal practitioner, recreational user, agricultural worker, trespasser, off-site resident, on-site resident and ecological receptors. The potential emission sources and activities in REE mining areas are summarized in Figure 2. 


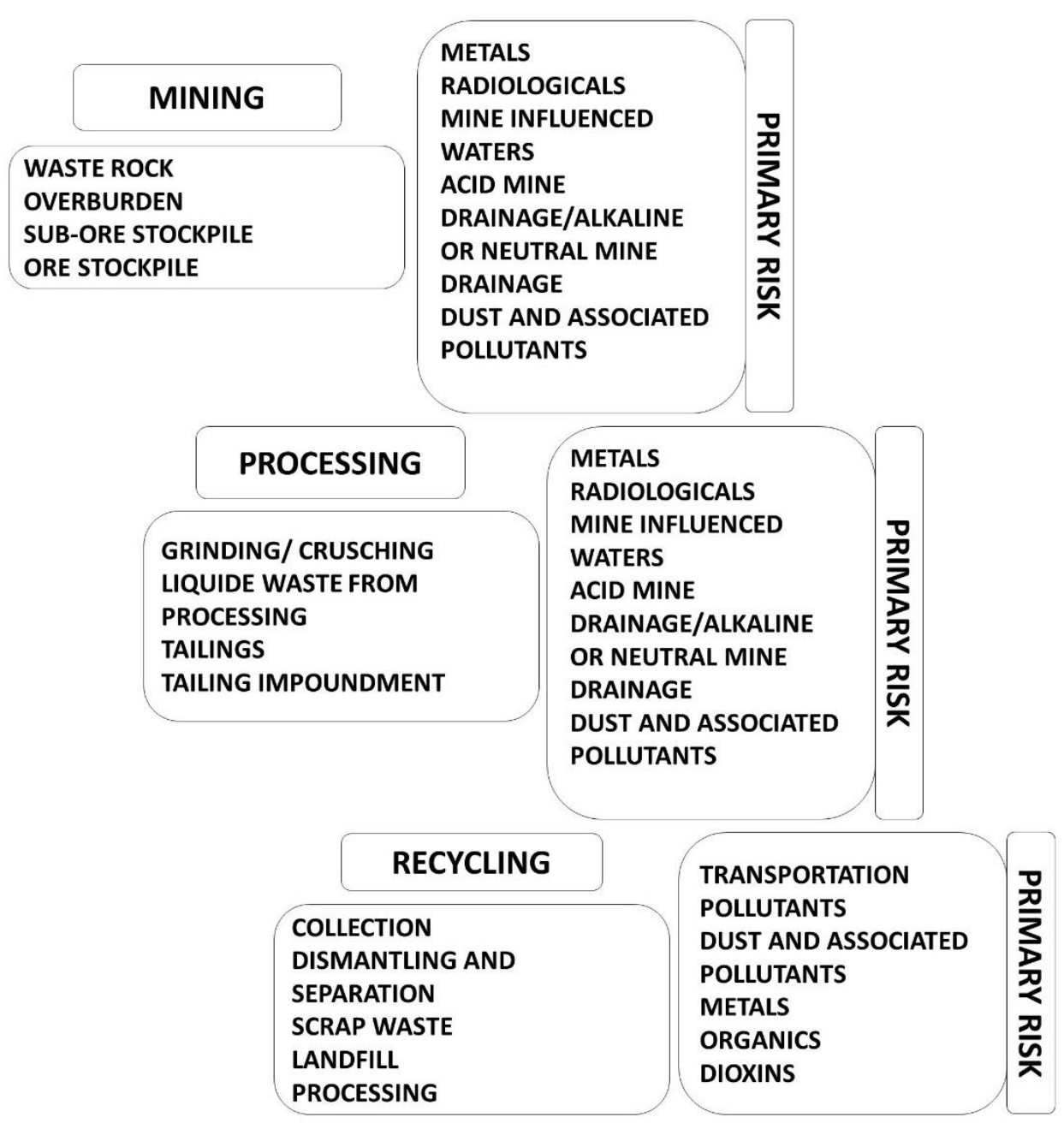

Fig. 2. Potential emissions point and pollutants associated with mining, processing and recycling of REE's

A preliminary literature search was conducted to identify human health, epidemiology and toxicity studies on REEs. The REEs is in general the potential human health risks.

\section{RESULTS AND DISCUSSION}

\subsection{Production process}

Primary deposits are minded by conventional opencast and underground methods using, for hard rock deposits, drilling and blasting. Secondary deposits are minded by dredge mining methods, as well as by manual surface collection and mechanized dry mining methods using conventional earthmoving equipment (Haqueet al., 2014). In the wake of mining hard rock stores are first crushed and ground and after that beneficiated, generally by methods for hot froth flotation (Protection, 2011). Placer deposits are beneficiated using wet gravity separation followed by dry processes such as magnetic and electrostatic separation to produce various types of mineral concentrates. Physical beneficiation increases rare earths content and usually also concentrations of the radioactive components (Protection, 2011). The thorium content in mineral concentrates varies from less than 0.1 to about $10 \%$, while the uranium content varies from very low values $1 \%$. Monozite has the highest thorium content, while bastnäsite (the largest commercial source of rare earths) contains relatively low 
concentrations of both thorium and uranium (Kumariet al., 2015). Rare earth mineral concentrates are chemically prepared to extract intermediate groups of rare earth compounds. Chemical treatment of mineral concentrates got from hard rock stores may start with roasting in air (calcining) to drive off carbon dioxide and oxidize cerium to the tetravalent state (Yaanantet al.,2017). This is by and large pursued by treatment with hydrochloric acid to dissolve non-cerium rare earths, yielding a marketable cerium concentrate which can be used directly as a low value product (for instance, for glass polishing) or further separated into high purity individual rare earths (Cordier and Hedrick, 2012). On the other hand, high temperature direct chlorination is a universal ore treatment process that incorporates with subsequent process steps. The process produces an anhydrous rare earth trichloride item that is appropriate for production of mischmetal. Chemical processing of mineral concentrates derived from placer deposits is usually accomplished using sodium hydroxide cake suitable from further processing with a variety of methods to separate thorium and individual rare earths, as well as a marketable by-product, trisodium phosphate (Haqueet al., 2014).

\subsection{REE recycling}

Recycling of materials containing rare earth elements is relatively difficult, which results from the complexity of macros structures of material and the electrochemical activity of these metals. The complexity of systems in which rare earth elements are used often requires manual segregation of components. Similarly, when done properly, manual dismantling is likely to have a low potential for worker risks resulting from exposure to hazardous materials. Mechanical dismantling and shredding can generate dust containing hazardous components. Dust control is particularly important when the items being shredded contain brominated flame retardants, because high temperatures during shredding could result in the formation of dioxins (Schluep et al., 2009).

Leaching processes using liquids such as nitric acid regia can cause a reaction of $n$ nitrogen oxide or chlorine gases formation and therefore must be controlled to prevent human and environmental impacts. In other processes that use strong acids or bases, safe handling of chemicals and dispose of resulting waste streams - in this case it is very important to protect workers and the environmental through the use of appropriate devices to purify the environment and through the strict application of individual measures to protect employees. In the other hand, thermal processes used for recycling can result in air emissions, liquid waste, and solid waste streams (Binnemanset al., 2013). Again, proper controls and handling are necessary to prevent human exposure and environmental impacts. In this case, it is worth considering the implementation of the principles of cleaner production. Implementation of a management and production control system in the company dealing with the recycling of products containing REE would optimize the generation of contaminants. In particular, it would prevent the introduction of these pollutants into the environment. Management in the cleaner production, consequently aims at limiting the raw materials resources, energy and human labor.

As reported by Schuler et al. (2011), when compared with primary processing, recycling of REEs will provide significant environmental benefits with respect to air emissions, groundwater protection, acidification and climate protection. This report also states that the recycling of REEs will now involve the majority of the impacts from mining operations and the impacts that can result from radioactive impurities, as is the 
case with primary production of metals. A large percentage of REE-containing materials are shipped to developing countries where they are recycled using informal processes. These informal operation can include manual dismantling, open burning to recover metals, de-soldering of printed wiring boards over coal fires, and acid leaching in open vessels. In almost all cases, these operations are uncontrolled and can lead to human exposure and extensive environmental damage. In addition, the processes used are generally less efficient and result in lower materials recovery than from more established methods (Weber and Reisman, 2012).

Rare earth elements are always very expensive and usually toxic. Taking this fact into consideration, it is clear that experiments on rare earths should be maximally effective i.e. small number of tests should give a large amount of obtained experimental data. It is possible only by the application of advanced data analysis methods as e.g. an image analysis (Gadek-Moszczak, 2017; Gadek-Moszczak and Matusiewicz, 2017), a parametric estimation (Baussan et al., 2014), a non-parametric approach (Pietraszek and Gadek-Moszczak, 2013; Gadek-Moszczak et al., 2015; Dwornicka et al., 2017; Pietraszek et al., 2017) or the most effective - the design of experiments approach (Pietraszek and Goroshko, 2014; Skrzypczak-Pietraszek et al., 2018). Such procedures lead to a proper prediction models which may be used as a base for a numerical simulation (Ferdek and Kozien, 2013; Domagala et al., 2018a; Domagala et al., 2018b) with the uncertainty estimation (Goroshko and Royzman, 2015), even by Monte-Carlo methods (Shao and Tu, 1995; Ohno et al., 2018) or fuzzy approach (Filo et al., 2018a; Filo et al., 2018b). Finally, it is sure that previous considerations should influence logistic processes in the metal industry (Nowakowska-Grunt and Mazur, 2015; Nowakowska-Grunt and Mazur, 2016) as well as low-level research and development in materials science: sintering (Deflorian et al., 1992), typical coatings (Zorawski et al., 2008; Radek and Bartkowiak, 2011; Scendo et al., 2014; Radek et al., 2017) or coatings modified by nanoparticles (Korzekwa et al., 2013; Korzekwa et al., 2016; Korzekwa et al., 2018).

\section{CONCLUSION}

Solid residue types and amounts resulting from rare earth separation processes depend on the exact processes used, but may include solvent extraction residue, filter cake or sludge, and scrapped filter cloths and equipment. The solvent extraction residue is an insoluble organic complex comprising non-halogenated organics and organic phosphate and chlorides; it is generally disposed of in controlled industrial waste facilities, although residue generated depends on plant conditions, plant size, and the degree to which spent solvent is recycled. In former in the USA, it was generated in quantities of about 100 t/a per plant, whereas in current operations in India the amounts are generally considerably smaller (Borra, C. R., et al., 2016).

The various process steps in the separation and processing of rare earths results in some airborne discharge. In rare earths production in India, gaseous effluents include hydrochloric acid vapor, chlorine and hydrogen sulphide and are assessed as part of the operational radiation protection program. These releases are controlled by alkaline (sodium hydroxide) scrubbers installed in the ventilation system to ensure compliance with local limits (Daiet al., 2016). It is reported from past operations in the USA that off-gases from the electrolytic reduction step include chloride, carbon monoxide and carbon dioxide from the graphite anodes, and hydrochloric acid fumes (Royen and Fortkamp, 2016). These gases were treated with water or alkaline 
scrubbers to cool them and to absorb particulates and hydrochlorid acid vapours. The partially cleaned gases were then contacted with sodium hydroxychloride solution, resulting in the formation of sodium hydrochlorite solution, which could be sold as a by-product.

\section{REFERENCES}

Ali, S. H., 2014. Social and environmental impact of the rare earth industries. Resources, 3(1), 123-134.

Balomenos, E., et al., 2017. The EURARE project: Development of a sustainable exploitation scheme for Europe's Rare Earth Ore deposits. Johnson Matthey Technology Review, 61(2), 142-153.

Baussan, E. et al., 2014. Neutrino super beam based on a superconducting proton linac. Phys. Rev. Spec. Top.-Accel. Beams, 17, art. 031001.

Binnemans, K., et al., 2013. Recycling of rare earths: a critical review. Journal of Cleaner Production, 51, 1-22.

Borra, C. R., et al.,2016. Selective recovery of rare earths from bauxite residue by combination of sulfation, roasting and leaching. Minerals Engineering, 92, 151-159.

Cordier, D. J., Hedrick, J. B., 2012. Rare earths. US Geological Survey, Mineral Commodity Summaries.

Dai, A. X., et al., 2016. Recycling of neodymium and dysprosium from permanent magnets. Penn Engineering.

Deflorian, F., Ciaghi, L., Kazior, J., 1992. Electrochemical Characterization of Vacuum Sintered Copper Alloyed Austenitic Stainless-Steel. Werkst. Korros., 43, 447-452.

Domagala, M., Momein, H., Domagala-Fabis, J., Filo, G., Kwiatkowski, D., 2018a.Simulation of Cavitation Erosion in a Hydraulic Valve. Mater. Res. Proc. 5, 1-6.

Domagala, M., Momeni, H., Domagala-Fabis, J., Filo, G., Krawczyk, M., 2018b. Simulation of Particle Erosion in a Hydraulic Valve. Mater. Res. Proc. 5, 1724.

Dwornicka, R., Radek, N., Krawczyk, M., Osocha, P., Pobedza, J., 2017. The Laser Textured Surfaces of the Silicon Carbide Analyzed with the Bootstrapped Tribology Model. Metal 2017: $26^{\text {th }}$ Int. Conf. Metallurgy and Materials, Ostrava, Tanger, 12521257.

Ferdek, U., Kozien, M.S., 2013. Simulation of application of FGM piezoelectric actuators for active reduction of beam vibrations. Acta Phys. Pol. A, 123, 10441047.

Filo, G., Fabis-Domagala, J., Domagala, M., Lisowski, E., Momeni, H., 2018a. The idea of fuzzy logic usage in a sheet-based FMEA analysis of mechanical systems. MATEC Web Conf., 183,art. 03009.

Filo, G., Lisowski, E., Domagala, M., Fabis-Domagala, J., Momeni, H., 2018b. Modelling of pressure pulse generator with the use of a flow control valve and a fuzzy logic controller. MSM 2018: $14^{\text {th }}$ Int. Conf. Mechatronic Systems and Materials, Zakopane, Poland, AIP Conf. Proc., 2029, art. 020015.

Gadek-Moszczak, A., 2017. History of Stereology. Image Anal.Stereol., 36, 151-152.

Gadek-Moszczak, A., Matusiewicz, P., 2017. Polish Stereology - a Historical Review. Image Anal. Stereol., 36, 207-221.

Gadek-Moszczak, A., Pietraszek, J., Jasiewicz, B., Sikorska, S., Wojnar, L., 2015. The bootstrap approach to the comparison of two methods applied to the 
evaluation of the growth index in the analysis of the digital $x$-ray image of a bone regenerate. New Trends in Comput. Collective Intelligence, 572, 127-136.

Goroshko, A., Royzman, V., 2015. Statistical methods for providing the stability of the solutions of inverse problems and their application to decrease rotor vibroactivity. Journal of Machinery Manufacture and Reliability, 44, 232-238.

Haque, N., et al., 2014. Rare earth elements: Overview of mining, mineralogy, uses, sustainability and environmental impact. Resources, 3(4), 614-635.

Kalantzakos, S., 2017. China and the Geopolitics of Rare Earths. Oxford University Press.

Korzekwa, J., Bara, M., Pietraszek, J., Pawlus, P., 2016. Tribological behaviour of $\mathrm{Al}_{2} \mathrm{O}_{3}$ /inorganic fullerene-like WS2 composite layer sliding against plastic. Int. J. Surf. Sci. Eng., 10, 570-584.

Korzekwa, J., Gadek-Moszczak, A., Zubko, M., 2018. Influence of the size of nanoparticles on the microstructure of oxide coatings. Mater. Sci. 53, 709-716.

Korzekwa, J., Tenne, R., Skoneczny, W., Dercz, G., 2013. Two-step method for preparation of $\mathrm{Al}_{2} \mathrm{O}_{3} / \mathrm{IF}-W S_{2}$ nanoparticles composite coating. Phys. Status Solidi $\mathrm{A}$ 210, 2292-2297.

Kumari, A., et al., 2015. Process development to recover rare earth metals from monazite mineral: A1 review, Minerals Engineering, 79, 102-115.

Liyananadirah M. S., et al. 2017. A Review of Rare Earth Mineral Processing Technology, Chemical Engineering Research Bulletin 19 (2017) 20-35.

Mubashir, M., 2018. Rare Earth Elements- A Review, Journal of Ecology \& Natural Resources, DOI: 10.23880/JENR-16000128.

Niciejewska, M., Klimecka-Tatar, D., 2018. Health problems among employees in small enterprises as a result of improper OHS management. 12th International Conference Quality Production Improvement, QPI 2018; Zaborze near Myszkow; Poland; 18 June 2018 through 20 June 2018; Code 139366 DOI: https://doi.org/10.1051/matecconf/201818301012

Nowakowska-Grunt, J., Mazur, M., 2015. Safety management in logistic processes of the metallurgical industry. METAL 2015: $24^{\text {th }}$ Int. Conf. Metallurgy and Materials, Ostrava, Tanger, 2020-2025.

Nowakowska-Grunt, J., Mazur, M., 2016. Effectiveness of logistics processes of SMES in the metal industry. METAL 2016: $25^{\text {th }}$ Int. Conf. Metallurgy and Materials, Ostrava, Tanger, 1956-1961.

Ohno, K., Esfarjani, K., Kawazoe, Y., 2018. Computational Materials Science. From Ab Initio to Monte Carlo Methods. Second Edition. Springer-Verlag GmbH, Heidelberg, Germany.

Pacana, A., Ulewicz, R., 2017. Research of determinants motiving to implement the environmental management system. Polish Journal of Management Studies, 16 (1), 165-174. DOI: 10.17512/pjms.2017.16.1.14

Pagano, G.,2015. Rare earth elements in human and animal health: state of art and research priorities. Environmental Research, 142, 215-220.

Pietraszek, J., Gadek-Moszczak, A., 2013. The smooth bootstrap approach to the distribution of a shape in the ferritic stainless steel AISI 434L powders. Solid State Phenom., 197, 162-167.

Pietraszek, J., Goroshko, A., 2014. The heuristic approach to the selection of experimental design, model and valid pre-processing transformation of DOE outcome. Adv. Mat. Res.-Switz., 874, 145-149. 
Pietraszek, J., Szczotok, A., Radek, N., 2017. The fixed-effects analysis of the relation between SDAS and carbides for the airfoil blade traces. Arch. Metall. Mater., 62, 235-239.

Protection, R., 2011. NORM Residue Management in the Production of Rare Earths from Thorium Containing Minerals. Safety Reports Series No. 68. International Atomic Energy Agency: Vienna.

Radek, N., Bartkowiak, K., 2011. Laser Treatment of Cu-Mo electro-spark deposited coatings. Physcs. Proc., 12, 499-505.

Radek, N., Pietraszek, J., Szczotok, A., 2017. Technology and application of electrospark deposited coatings. Metal 2017: $26^{\text {th }}$ Int. Conf. Metallurgy and Materials, Ostrava, Tanger, 1432-1437.

Royen, H.,Fortkamp, U., 2016. Rare Earth Elements-Purification, Separation and Recycling, IVL Swedish Environmental Research Institute.

Scendo, M., Trela, J., Radek, N., 2014. Influence of laser power on the corrosive resistance of WC-Cu coating. Surf. Coat. Tech., 259, 401-407.

Schluep, M., \& Programme des Nations Unies pour l'environnement, 2009. Recycling, from E-waste to resources. UNEP DTIE; StEP Initiative.

Schüler, D., et al., 2011. Study on rare earths and their recycling,Öko-Institut eV Darmstadt.

Shao, J., Tu, D., 1995. The jackknife and bootstrap. Springer Science+Business Media, New York.

Skrzypczak-Pietraszek, E., Reiss, K., Zmudzki, P., Pietraszek, J., 2018. Enhanced accumulation of harpagide and 8-O-acetyl-harpagide in Melittismelissophyllum L. agitated shoot cultures analyzed by UPLC-MS/MS. PLoS ONE 13, art. e0202556.

Weber, R. J., Reisman, D. J., 2012. Rare earth elements: A review of production, processing, recycling, and associated environmental issues. US EPA Region.

Yaanant, N., et al.,2017. Study on Developing Safety Infrastructure for Mineral Processing Waste (NORM Waste) and Contamination Monitoring at the TINT Rare Earth Research \& Development Center, Khlong 5, Pathumthani, Thailand. Journal of Physics: Conference Series (Vol. 860, No. 1, p. 012044). IOP Publishing.

Zepf, V., 2013. Rare Earth Elements: What and where they are.Springer, Berlin, Heidelberg.

Zhu, Z., et al., 2015. Separation of uranium and thorium from rare earths for rare earth production-A review. Minerals Engineering, 77, 185-196.

Zorawski, W., Chatys, R., Radek, N., Borowiecka-Jamrozek, J., 2008. Plasmasprayed composite coatings with reduced friction coefficient. Surf. Coat. Tech., 202, 4578-4582. 